\title{
India's Women Legal Academics: Who They Are \& Where You Might Find Them
}

\author{
Swethaa S. Ballakrishnen \& Rupali Samuel
}

Legal institutions in India have historically been inhospitable sites for women (Mossman 2006; Sorabji 2010; Mishra 2016; Rajkotia 2017). Unlike the trend of increasing feminisation in legal professions around the world, women constitute less than $10 \%$ of all lawyers in India, a percentage that has not changed in the last half century (Michelson 2013; Ballakrishnen 2019). And outside a few small pockets of exceptionalism (Ballakrishnen 2017, 2018), systemic biases and gendered hierarchies continue to be relevant for today's lawyer. Not that much is different in the legal academy: despite some recent increases in the gender ratios, Indian law schools are, and predominantly have been, led by male torchbearers. Men are more likely to be academic deans and vice-chancellors than women. Men are more likely to have tenure and be represented in academic councils. They are cited and referenced in the classroom more frequently - because they are both likely to be curating the teaching syllabi for these classrooms and because they are more likely to have written the books that are considered canonical for students of law ${ }^{1}$. Together, this combined positionality has made the authoritative male voice, in the classroom and curriculum alike, not just predominant, but also 'natural'.

This is not to say that this predominance has been without dissent and challenge and particularly over the last half century, this predominant male voice has existed alongside a strong, coherent feminist voice. But despite the increasing number of women in higher education more generally, women's voices - especially, the feminist voice as a counterhegemonic, subversive, political voice- has not had the same degree of citation and classroom currency as the former. As early as 1953, Lotika Sarkar, India's first woman to study and graduate from Cambridge University (PhD 1951), joined the University of Delhi's Law Faculty as the first female lecturer. And well after her long career as a law professor (1953-83), she was celebrated as an eminent jurist and central figure to the women's right movement. But even as Sarkar remains a visionary mentor for many ${ }^{2}$, her reach in the generic law classroom has not been as canonical or long lasting as that of her male contemporaries (or even successors). Even for those of us lucky enough to have been taught by Sarkar's students and junior colleagues (as both of us writing this chapter, were), Sarkar was a feminist icon whose work was read and re-read in small seminars that were fuelled by self selection; those of us that read her, read her out of inclination, not so much out of requirement.

Scholars have made the case for Indian legal education as an essential tool for prying feminist methodology and analysis from the 'ghettos of small, specialised seminars and into a

${ }^{1}$ For example, Bhadbhade at ILS has the distinction of editing the 2013 edition of Pollock and Mulla's Commentary on the Indian Contract Act, a core text on contract law that has formed the basis for much judicial doctrine over the last century. However, even the publisher's catalogue does not mention her name, see www.lexisnexis.in/the-indian-contract-act-1872.htm.

${ }^{2}$ For example, on Sarkar's demise she was fondly remembered by her students, especially on progressive blogs and feminist websites, for being pivotal to shaping their politics and activism (Dhanda and Parashar 1999; Ramanathan 2013; Kannabiran 2014). 
modified, but mainstream, law classroom' (Parashar 1999: 108). But even in 'elite schools' charged with the cause of progressive pedagogy, this has not happened with any committed consistency. As Sircar notes (2016:136), 'Not surprisingly, the words patriarchy or feminism were not uttered even once in class, let alone gender.' It is this shape that the teaching of 'women and law' has taken within the legal academy that betrays the radical roots of feminist legal scholarship and activism in India. Similarly, Vasudha Dhagamwar, Sarkar's junior by a decade, is better celebrated as an activist scholar (she established Multiple Action Research Group 'MARG', one of the country's leading NGOs, specialising in legal awareness, advocacy and public interest law), rather than remembered for her teaching at the University of Pune or her important research on a broad range of topics including family law, displacement and industrial development ${ }^{3}$.

We use these historical examples to show how even the most celebrated of these women legal academics are still read and remembered at the periphery: and often by other women. Feminist scholarship and scholarship by women has had to constantly face this double bind of both carving a niche for itself and still, at the same time, recalibrating that niche to have more breadth. For the most part, however, the few women legal academics that have historically carved a name for themselves still remain very much on the sidelines of dominant law school curricula, thought and engagement. A student, even in one of India's 'progressive' law schools can go through it without having engaged with feminist scholarship or writing that they can attribute to a particular woman scholar. ${ }^{4}$ In this light, it is not surprising that for many students, feminist identities and interventions within these sites are 'radical' and/or 'unnecessary'.

This chapter is situated in these institutional crevices that have shaped women's careers in the last 65 years in Indian legal academia. We make our case in two parts - first, we trace the women legal academics who have been central to the Indian academy, their role as institutional change-makers and their ability to form more inclusive and gendered spaces. Next, we trace the women who have been central to the creation of legal scholarship without being in the academy. Together, we suggest that where we look for the women legal academics in India is central to how we archive their contributions. We argue that looking to assess the wealth of the research only via the scholar-academic model would lose sight of many others who have made important interventions without claiming this space. Our hope in archiving their collective contribution is not only to shed light on these multi-faceted academics, but also to draw attention to the problematic context of the historical law school

\footnotetext{
${ }^{3}$ In fact, Sarkar and Dhagamwar were both co-signatories along with Upendra Baxi and Raghunath Kelkar to a famous open letter to the Supreme Court in 1979 that called for a change in legislation following the Mathura case, where a 16 year-old tribal girl was gang-raped while in custody. But the letter is more colloquially attributed to Baxi than it is to either of his female co-signatories.

${ }^{4}$ A striking feature of a review of prescribed readings in mandatory courses (on file with the authors) in any of the law schools mentioned above is the absence of writing by women, with the exception of books in family law.

${ }^{5} \mathrm{~V}$ S Elisabeth, on feminism within the student community at the National Law School, Bangalore: 'Most of the women students have been hesitant to openly proclaim that they are feminists fearing the backlash or worried that they will not be so popular with their male classmates and friends or because they just do not think anything is wrong with the world as it is, having accepted the inequalities as a given....Most people think of feminism in terms of the most radical feminists and most students who call themselves feminists would prefer a liberal feminist perspective, something that does not radically change the world they live in and are familiar with.' (Mukhija 2016)
} 
site (and the ways its gendered and hierarchical blueprints might still stand in the way of real inclusivity for young women legal academics in the country).

\section{Women in the Legal Academy}

The current landscape of legal education in India comprises broadly three types of academic institutions - the National Law Universities (NLUs), the Law Departments at public universities and those of private law colleges. ${ }^{6}$ While many of the public universities are older institutions or 'legacy schools' from the colonial era (Gingerich and Robinson 2014), the private law colleges are slightly younger creations. In contrast, the NLUs emerged from radical reforms in legal education in the late 1980s geared towards creating independent, interdisciplinary and research-intensive institutional spaces with high entry barriers that would foster a new generation of socially engaged lawyers ${ }^{7}$ (Baxi 1976; Krishnan 2004; Menon 2010). Further, unlike both the legacy and most private law schools, NLUs also enrolled and graduated close to equal numbers of women and men. These patterns of enrolment become important, especially as we consider the demographics of their respective faculties.

The presence of women scholars in law schools was certainly an exceptional circumstance for the better part of the $20^{\text {th }}$ century. Sarkar was the only female scholar at the Faculty of Law, Delhi University until she was joined by S K Verma in 1975. It would be almost another decade before the school would welcome more female faculty - family law scholar Poonam Saxena (1982), juvenile justice scholar Ved Kumari (1986) and family law scholar Kiran Gupta (1986). And it would be another two decades before the Indian Law Institute would hire Verma as its first female director (1998). In schools outside of Delhi this representation wasn't that much different. For example, family law and children's rights scholar Jaya Sagade started at the ILS Law College, Pune (established in 1924) in 1981 and Nilima Bhadbade, a leading authority on contracts joined the faculty only in 1993. As we indicate in Table 1, the current survey of faculty listings across the top law schools in the country reveal that most senior posts in law schools are still predominantly male, although numbers of women legal academics have been steadily rising at the junior levels.

[Table 1 About Here]

This lack of representation is particularly surprising in the case of the NLUs. NLUs have mostly gender-equal cohorts where women enter and graduate at approximately the same rates as men (Basheer \& Sharma 2014). In turn, this has meant that men and women alike are socialized into more gender-represented professional environments, in stark difference to other kinds of elite professionals (Ballakrishnen 2018). Yet, despite being really good for female law students, these relatively new schools are not similarly favorable for women law

\footnotetext{
${ }^{6}$ See the Bar Council of India Rules on Legal Education for a detailed outline of the various kinds of colleges and programs that are offered in law schools across the country: http://www.barcouncilofindia.org/wpcontent/uploads/2010/05/BCIRulesPartIV.pdf

7 The progressive vision of these law schools fostered early optimism that these spaces would engage in law reform that reflected the social justice mandate of the Constitution (Stewart 1995). The creeping neoliberal takeover of the University space has told a different story (Gingerich and Robinson 2014).
} 
faculty. A survey of faculty listings in the six top NLUs ${ }^{8}$ reveals that women are increasingly entering the formal academic space. Even so, very few women (eg Poonam Saxena, the current Dean at NLU Jodhpur) hold senior positions in these institutions. Even after 30 years, NLSIU, the first of these NLUs, has only one (of seven) full time faculty members who is a woman (and, incidentally, she is a history rather than a law professor). The National Law Institute University (NLIU) and the National University of Juridical Sciences (NUJS) have no women as full professors. Amongst the more junior faculty positions, the share of women is rising, although men continue to dominate in terms of numbers (Table 2).

\section{[Table 2 About Here]}

Intriguingly, the older public schools, whose historical representation used to be starkly male, show significant reversals. Not only are women better represented in the faculty of these schools than in their NLU counterparts, they are also better represented in senior positions. For eg, each of the three law departments (Campus Law Centre, Law Centre 1 and Law Centre 2) at Delhi University is headed by a woman - Usha Tandon, Ved Kumari and Kiran Gupta respectively. Ved Kumari is presently the Dean of the entire Faculty of Law at Delhi University.

Similarly, newer schools built on the NLU model - public and private alike - have been favourable to recruiting women to senior positions - Rose Varghese heads the National University of Advanced Legal Studies at Kochi, Kamala Sankaran will start as Tamil Nadu National Law School's second vice chancellor. Of the newer private schools, the Institute of Law at NIRMA University was set up in 2007 with Purvi Pokhariyal as director. The Jindal Global Law School, with its sizeable faculty, active research centres and international collaborations with reputed law schools (including a number of Ivy League schools) has nearly 50 per cent women in the junior faculty, but far fewer women in senior positions.

[Table 3 About Here]

\section{Beyond Numbers: Positionality of Women Faculty in Indian Law Schools}

In addition to telling us about inequality in career progression between male and female academics, this representation of women in faculty positions is important because it fails to respond to a changing demographic of female students in these schools. Unlike early student cohorts that were predominantly male, there has been a steady increase of female law students (even if not practising lawyers, eg, Michelson 2013), especially in the NLUs that have a gender-equal student body (Basheer and Sharma 2013, Jain, et al 2015). Still, numbers only tell us one part of the story and they do not fully speak to the qualitative experiences of these women law students or legal academics.

${ }^{8}$ This includes the 5 oldest NLUs: NLSIU, NALSAR, West Bengal National University of Juridical Sciences at Kolkata (NUJS), National Law Institute University at Bhopal (NLIU, Bhopal), National Law University at Jodhpur (NLU, Jodhpur). National Law University at Delhi (NLU, Delhi) set up in 2008 has also been included in this list as it has one of the most active set of research centres and has one of the largest faculty amongst all the NLUs. 
In line with other studies (eg, Gutiérrez y Muhs et al 2012) that track women's entry and success in academia, our conversations with these women faculty confirmed a range of gendered hurdles that plagued their experience including few mentors, difficult work environments where they had to prove themselves over and over again and gendered identities. Many female academics - especially at junior levels - continue to be hired on an ad-hoc basis - a position that does not lend itself to an active or radical political voice. While the question of voice plagues all junior and temporary hires, women do not always enjoy the same mobility as men in the wider legal profession and are therefore more constrained. These hires are also often justified, as one senior professor explained, as good fits for women who seek these positions as intermediate career fillers as opposed to primary career choices. But these justifications are exactly what pose a systemic issue for women in academia. Such positions are not advantageous long-term academic choices because they carry with them the classic factors that freeze such careers - contract employment, no job security, low pay, heavy teaching loads and no research budgets. Further, while work-family balances might be better navigated with a teaching position, they also come without the protection of tenure. As a result, in many of these schools women 'remain' as junior, nonpermanent faculty.

\section{Feminist Voices in the Law School Space}

The other way in which numbers do not tell us the whole story is that demographics of female faculty don't automatically mean the creation of feminist or even female friendly spaces. And while there have been women who have created spaces of critical inquiry, positioning themselves as feminists within the law school space has - unlike for their male counterparts $^{9}$ - come at a steep price (Mukhija 2016). Much like the courtroom, women's acceptance in legal academia has hinged on the condition that they inhabited as de-sexed selves. For example, when Lotika Sarkar began teaching at the University of Delhi in the 1950s, she strongly asserted that she was not a 'woman teacher', but a teacher.

Women have had to fight to make themselves heard in debates, especially on pedagogy. The most recalled historical account of this curtailment of women's voices is perhaps the dictum against Sarkar for teaching rape in the context of criminal law (Haskar 1999, Baxi 2008b, Ramanathan 2013, Baxi 2016). The pedagogical debate about teaching rape in the classroom is not unique to India (for example, Gersen 2014). But the objection to Sarkar talking about rape was that she would have to also talk about a sexual act to a mostly male class, which would be inappropriate for a woman (Haksar 1999:73). Sarkar's polite dismissal of this diktat is reflective of her feminist voice. But it is even more telling of the environment she had to cultivate it in. Ved Kumari, another senior professor at the same school, explains that even almost a half-decade later, similar sensitivities continued to prevail in the criminal law classroom. Kumari was even asked not to assign judgments of the Supreme Court on rape as classroom reading, for fear of offending the norms of propriety. Beyond enforcing a moral code, these kinds of prohibitions rest on the threats of subversive possibilities of a woman

\footnotetext{
${ }^{9}$ In contrast to NLU Professor V S Elizabeth's narrative (Mukhija 2016) of having to 'fight at every stage for every promotion', male academics like Professor Upendra Baxi have had the choice of both speaking their mind and staying in public graces for such openness. See, eg, Baxi (2007) describing the National Law School as a 'prototype of homogenized, elite theorizing' even as he continues to be regarded as the most prominent legal academic from India and serves as visiting faculty at numerous of these NLUs.
} 
talking about consent (and, presumably, thereby constituting herself as a sexual agent). Sarkar might have hated the term 'woman teacher', but in the law school spaces that she and scholars after her inhabited, their gender remained extremely relevant.

At the heart of this debate on pedagogy was the nature of the space to be occupied by gender in the legal academy. The first kind of intervention involved discussions around issues and laws pertaining to women - either in regular courses or in specialised courses. While discussions on women and law were not absent, particularly in the context of femalespecific legislations, these discussions were often rudimentary and bereft of any feminist perspective (Mazumdar 1999, Baxi 2008a). At a 1996 conference of Indian and Australian legal academics, Dhanda and Archana Parashar faced resistance to their attempts to introduce feminist legal methods (and, thereby, curriculum) as a core pedagogical mode across various subjects taught at law school. 'Feminism we were told could be taught as one more school of jurisprudence,' they write about their engagement with their peers at that event (Dhanda and Parashar 1999). Contemporaneously, Ved Kumari was engaged in the same debate at Delhi University. Here the dominant opinion was that she should just offer a women and law course instead of having gender introduced in all mainstream classes - a view, interestingly, as Dhanda and Parashar (1999: 30) note, that Sarkar was not opposed to for the reason that 'gender components' in courses would be the first casualty in any syllabus cut. A multi-year debate resulted in the introduction of a 'gender justice' seminar course at the University. Yet, even now, Kumari admits that it is a 'war she hasn't won' as very few people enrol in the gender justice class.

The other more disruptive claim - and, concurrently, elusive goal - has been for a feminist methodology as a critical part of studying any course in the law school. This claim was most explicitly made at a 2005 IAWS (Indian Association for Women's Studies) conference where legal academics shared their experiences of incorporating feminist jurisprudence and methodologies in their classes and explicitly argued that legal pedagogy required an upheaval to incorporate more feminist critiques. However, a review of publicly available syllabi in many of these law schools suggests that no such feminist critique is incorporated into the main curricula.

But this does not mean there have not been attempts to change this. On the one hand, some efforts have been made to 'introduce gender', so to speak, within the law school curriculum. For example, the Bar Council of India Rules on Legal Education, 2008 prescribe 'Gender Justice and Feminist Jurisprudence' as an optional course in the 'Constitutional Law Group' of subjects to be offered. And Ratna Kapur who taught at NLSIU in the 1990s, with visiting scholar Brenda Cossman released a Special Issue of the NLSIU Law Journal entitled 'Feminism and Law' in 1993, followed by an edited volume of essays titled 'Subversive Sites: Feminist Engagements with Law in India' in 1996. Both these resources contained critiques of legislation and cases that were rooted in feminist jurisprudence and could have been useful pedagogical resources for the classroom. However, neither was used in any systematic way for this purpose (Sircar 2016). In the same period, Kapur, through one of the law school's research centres, the Centre for Women and the Law, was also commissioned to conduct grass root consultations and recommend reform in the laws relating to sex work and obscenity. However, as Kapur notes in a recent conversation with Sircar (2016: 148) regarding her experience at the NLSIU, the law school itself, despite its overt progressive 
agenda, 'hardly had any feminist spaces' and only 'some marginal engagement in a couple of courses in jurisprudence'. She elaborates:

"In all honesty, there was very little (feminist legal research) emerging from the legal academia in India. And that's because feminism itself was not taken very seriously in law faculties... There were however feminist activists such as Flavia Agnes, who was doing feminist lawyering in courts, and bringing that experience to her writings." (Sircar 2016: 149)

This closely reflects Ann Stewart's similar critique of the law school space more than two decades ago, where she notes that 'in India, feminism has yet to establish itself firmly within the legal academy' (Stewart 1995: 254).

Twenty years on, not that much has changed. There continue to be student led organisations and less-formal student associations (eg, reading groups, internet forums, ad hoc demonstrations) with varying degrees of exchange around feminist issues, but more institutional interventions remain rare. Further, conversations around pedagogy are mostly marginal, even in progressive law schools. And women faculty - to the extent they are even involved in the debate - continue to be engaged in this struggle to have feminist jurisprudence as a necessary component of legal pedagogy (Elisabeth 2011). For example, a 2005 conference addressing 'critical problems facing contemporary legal education, especially legal education in large parts of the global south' conducted in collaboration with NLSIU had no women faculty from an Indian law school on any of its panels (CSCS 2008). A few dedicated professors continue to make critical interventions to their classroom and to scholarship on legal pedagogy (eg, Kannabiran 2005; Dhanda 2009; Baxi 2016) and some junior scholars are invested in continuing this tradition. However, these bubbles remain narrowly accessed by a self-selecting cohort of students with an already developed interest in law and gender (Nair 2013).

\section{Gendered Status and Attaining Distinction}

Some women have used the law school space to build scholarship around micro-fields within legal studies. ${ }^{10}$ However, the status of women who attain distinction in their field or seniority in an institution is not always comparable to the acclaim enjoyed by their male counterparts. Women's scholarship is much less likely to be prescribed as reading (even within their own law schools!) and women are much less likely to be invited to law schools as guest speakers or domain experts, especially outside the field of gender. ${ }^{11}$ Although not as

\footnotetext{
10 Prominent among these has been Amita Dhanda's work on disability rights, Kamala Sankaran's work on labour law and, although known foremost for her feminist scholarship, Kalpana Kannabiran's work on law, social movements and inequality. Of the newer generation of academics some examples include, Chinmayi Arun as Executive Director at the Centre for Communication Governance at NLU-D, has been at a leading figure in media and internet governance related law and policy. Aparna Chandra, also at NLU-D has been working closely with the Law Commission of India and various governmental bodies on judicial process reform and systemic reforms to the criminal justice system.

11 Only five of the 59 people invited as guest speakers to NLSIU from July 2013 to June 2014 were women. Only three of the 35 people invited by the law school to give guest lectures at NLSIU from July to December 2015 were women, of which only one was a legal academic (from a foreign law school). See
} 
widely discussed as in other parts of the legal profession (eg, Sood 2013; Mishra 2016), sexual harassment has been a serious issue, even against senior faculty (Legally India 2012). Beyond targeted incidents, women faculty also navigate other informal codes of casual sexism in their day-to-day activities including the assignment of low-status (and gendered) hospitality or care-taking responsibilities within these schools. ${ }^{12}$

Further, of the women who are now considered serious academics within these law schools, many have had circuitous paths into these institutions, that have enabled their innovative interventions. For example, Kalpana Kanabiran was a sociologist given tenure at an NLU, Dhanda joined an NLU with 15 years of dedicated legal research experience at the ILI, Ratna Kapur studied and did all her research outside Indian institutions before returning to an Indian faculty. As Dhanda observes about her own trajectory, this might have been an important structural condition in allowing for each of their innovative and inspiriting careers:

"In the manner in which Indian academia functions, junior faculty are on the receiving end of a lot of interfering supervision which often curbs innovation and initiative, and by the time this faculty reaches the top bierarchy, it has gotten used to the beaten track and the established way of doing things. As I joined the academy at the top of the hierarchy, I escaped this supervision..."

These innovations within unhelpful structural conditions are important to take note of because while they are testament to the vision of these successful women, they reveal the still-biased environments within which this success has been possible: in being predicated by specific circumstances (rather than by intentional policy or institutional effort), they are indicative of an individual-level success despite the system, rather than as one facilitated by it. These accounts also simultaneously highlight the unfortunate impossibility of replication. For young women seeking to rise in the imminent footsteps of these women, these examples offer inspiration. But as cases produced by circumventions within the system rather than by explicit structural conditions meant to recruit and retain female faculty, they do not promise similar pathways for other women seeking to find their place within these academic spaces.

\section{$\underline{\text { Role of Women Academics as Institutional Change-Makers }}$}

Despite the limitations described above, many women have been crucial in institution building - both within and outside the law school. Following her appointment by the Government of India to the Committee that prepared the Towards Equality Report (which would become a historic and foundational legal equality doctrine), Sarkar set up in 1974, along with certain other scholars and activists, ${ }^{13}$ an autonomous research institute called the 'Centre for Women's Development Studies' (CWDS). CWDS would start the first women's studies journal in India, ${ }^{14}$ and was a founding member of the Indian Association for

www.nls.ac.in/resources/guestlecturesjulytodec2015.pdf. Similarly, only three of 17 guest lectures conducted at Nalsar in the period between September 2015 - February 2017 were by women of whom none were academics. ${ }^{12}$ A classic case of this is women (both faculty and students) being called upon not to receive guests, but to simply present flowers to them. In that light, Elisabeth comments: 'The kind of responsibilities given also demonstrate the gender inequality. A simple example is the convocation, the duties allocated to women faculty have been flower arrangements, stage decoration etc. Not one of us, to the best of my knowledge, have ever been given the responsibility to receive the CJI or the Chief Guest and escort them to Law School.' See (Mukhija 2016).

13 This included another author of the report and founder-Director, Vina Mazumdar.

${ }^{14}$ Samya Shakti was brought out by CWDS from 1988 to 1994. 
Women's Studies (IAWS), an association set up to further women's studies perspectives in different disciplines (www.iaws.org.).

Women faculty continue to be consulted by the government as experts in various legal reform initiatives. However, it bears note that these are often confined to gendered laws such as rape, domestic violence and dowry harassment ${ }^{15}$ and even in these interventions, women do not always occupy significant positions. ${ }^{16}$ Women in law school faculties have also been at the helm of facilitating various research centers and interdisciplinary networks. ${ }^{17}$ These cross-disciplinary networks of scholars, lawyers and researchers have been important sites for the sharing of feminist legal scholarship, especially as an important component of indigenous critical legal studies. However, there is still much to be done in terms of locating feminist legal interventions in the legal academic space. ${ }^{18}$ Even just in terms of demographics, while the presence of women in legal academia is not, in itself, the same thing as having feminist legal training in the curriculum and/or classroom; its absence further isolates any chance of such training entering a mainstream law classroom.

\section{Locating the Legal Academic Outside the Law School}

As we suggest above, law schools have bred a mostly sterile environment for gender egalitarian recruitment and retention where women and their scholarship are in the numeric and intellectual minority. And, more specifically, despite a notional increase in women across law faculties, both at entry and in more senior positions, law schools themselves have been relatively poor petri dishes for producing (or using in pedagogy) feminist legal scholarship. As Pratiksha Baxi (2008: 80), a senior legal scholar at the Center for the Study of Law and Governance at Jawaharlal Nehru University who is not formally trained in the law and has, noticeably, never inhabited a mainstream law school space, suggests: 'Techniques of censorship and repression have also been annexed by malestream legal publishers who have continued to produce

\footnotetext{
${ }^{15}$ Notable exceptions to this are Dhanda whose expertise has been sought by UN bodies, the Government of India and various State governments in developing legal and policy reform in the field of disability rights; Ved Kumari who has contributed to the development of law relating to juvenile justice in India; Aparna Chandra, who has worked closely with the Law Commission in studying judicial process reform.

${ }^{16}$ For example, only one of the three members of the Justice Verma Committee which was tasked with reviewing sexual assault law in the country in 2013, was a woman, Justice Leila Seth. The 'overall-in-charge' of the Committee was their counsel who is man (with no specific expertise in gender related work) who led a team of 14 lawyers of which 3 are women. The only law professor on the team, Dr Mrinal Satish, has been working in the area of sexual assault law, but notably is not a woman. (Justice Verma et al 2013)

${ }^{17}$ For example, the Centre for Health, Law, Ethics and Technology (CHLET) which is engaged in research on access to drugs, health and sexuality, sexual minority rights, reproductive rights; the Law and Social Sciences Research Network (LASSnet) and the Gender and Law Association (GALA). LASSnet has conducted four conferences in different parts of India and Sri Lanka since 2009. Their programmes gives a broad overview of important law and society scholarship and more specifically a glimpse into feminist legal scholarship over the last decade. See www.lassnet.blogspot.in. Set up in 2003, GALA is a network of academics and advocates in India and US 'collaborating to promote women's rights by mainstreaming gender into Indian legal education.' See www.wcl.american.edu/gender/wilp/gala/website/

${ }^{18}$ Nowhere is this need more urgent than in creating spaces that allow for concerns around sexual violence and harassment to be better aired. Sexual harassment committees are statutorily mandated in all universities. However, there is often immense pressure for students to not pursue claims in this regard. And women making public feminist interventions are often ridiculed and face harassment, online hate and rarely ever get broad public support.
} 
masculinist genealogies of the law'. However, the historic absence of productive environments within these schools to foster women academics doesn't necessarily mean they don't exist. Women have contributed to legal scholarship despite being outside the Academy. If we are to archive their collective contribution, then, female representation in law schools cannot be the only measure to understand the intersections between the feminist movement, law schools and society. The task demands that we look at the women who contributed to legal academia from outside the law school, women who resisted the law school environment because it wasn't a conducive space.

One could argue even further that women have produced such scholarship not just outside the academy, but often times, because of this outsider status. Kapur and Parashar were, for example, both academics who taught and published outside the country for most of their careers. One form of this 'outsider' status is the case of Indian and Indian-trained women legal academics like Prabha Kotiswaran (Kings College) who practise, teach, research and publish in spaces outside the country. Another variation are socio-legal academics like Asha Bajpai who despite training in law have built careers in social science institutions. Bajpai's scholarship on child rights and gender issues have been widely published but her recognition as a senior scholar has not been generated within a law school, but instead, one of the country's premiere social science institutions, when in 2012, she was appointed the founding dean of the School of Law, Rights and Constitutional Governance at the Tata Institute of Social Science, Mumbai.

One prominent parallel space to the law school for women legal scholars was the standalone research think tank space. Early records of the Annual Survey of Indian Law (ASIL) and the Journal of the Indian Law Institute (JILI) reveal the scholarly contributions of Alice Jacobs and Kusum (contemporaries of Baxi and Sarkar), both of whom never taught in formal law schools, but, instead, were researchers at the Indian Law Institute 'ILI', a longstanding institute for legal research. Jacobs authored the segment on Constitutional Law and Kusum, on Family Law. Sarkar, their contemporary, authored a new segment titled, Women and the Law from 1985. All these scholarly reports made note of developments in the law for each year, including international developments. It is not a stretch to presume that for those who taught and did research at the time, these would have been seminal reference texts in their field - but they are almost never used in the contemporary classroom.

Even for scholars who have had law school affiliations, creating these spaces outside - and sometimes within - law schools have been crucial to foster the atmosphere their scholarship demanded and/or do the legal advocacy they might have felt restrained to do within the periphery of the law school. Vasudha Daghamwar is more famous for her legal advocacy and literacy programs she did outside of a law school (through her organisation MARG) than for her initial tenure as a law professor in Pune. Kapur set up the Center for Feminist Legal Research in 1995 as a space 'for research unavailable either within the institutional space of legal academia, or the activist space of feminist politics' (Sircar 2016: 148). Similarly, Kannabiran's political and advocacy voice as a socio-legal scholar (first at Asmita and currently at the Council for Social Development) has been more piercing and productive from her tenure outside a formal law school than within it (Kannabiran 2012: xiv). Other examples include spaces with strong feminist voices like Sarai, Centre for the Study of Developing Societies, The Internet Democracy Project and Chinmayi Arun's Center for Communication Governance within the National Law University, Delhi. 
Academic spaces like the CWDS, the Self-Employed Women's Association of India SEWA and the feminist journal Manushi have been historically important for similar reasons. These were not technically stand-alone 'law' or even law-related think tanks or spaces, but they were still central to being spaces where legal research and research that would influence law would emerge. And strong women (often, not legally trained) were at the helm of these institutes. Together these spaces and the people within them reinforced each other. For example, Sarkar's involvement in CWDS was crucial to her identity as a scholar. And Ela Bhatt's involvement at SEWA produced scholarship and advocacy that was central to the human rights movement (eg Bhatt 1989); Kumud Sharma at CWDS, similarly, was neither in a law school nor a lawyer but published exhaustively about gender rights and legal remedies (eg, Sharma 1998). For other scholars who were not legal academics in the technical sense (and perhaps even more isolated from the academy than the scholars who worked in a place like the $(L I)$, these spaces and their proximity to lawyers made them work much like legal research organisations with a keen focus on women's rights.

Similarly, Indian legal scholarship has been advantaged by a wealth of practitioners and activists whose legal writing and public intellectualism has shaped its rhetoric and discourse. Nandita Haksar is known foremost as a human rights lawyer and activist but was also one of the first women practitioners to come back to teach from that position of seniority and expertise in a law school (albeit ad hoc). ${ }^{19}$ This tradition continues with a few contemporary scholars like Jayna Kothari and Menaka Guruswamy who occupy the law school space without formal positions, but as practitioners whose discourse inform current law and legal social movements.

In contrast, there is a little more heterogeneity among those women who have claimed the activist space while continuing to influence legal academia. Practitioner-activists include Sudha Bharadwaj, a lawyer and trade unionist who has worked on land acquisition/civil rights issues for three decades and Usha Ramanathan, who is considered one of the country's leading experts on law and poverty. And, of course, there remain pure activists with no law credentials or connections, who have been pre-eminent to civil rights movements (eg, Abha Joshi's work on tribal women's rights, Aruna Roy on informal labor). Despite their considerable authority and recognition in other circles, law schools remain relatively blasé about engaging with these scholars in any serious fashion. For example, Ramanathan's discerning dissent on a range of policy measures has been central to informing public debate and despite being consistently recognised by a range of international audiences, she has been rarely been invited to speak at local law schools.

But not all activists that have influenced legal reform and movements have done so solely from the practitioner/activist space. Most notable in this classification is perhaps Indira Jaising, a senior lawyer in the Indian Supreme Court, whose pioneering NGO Lawyers Collective was the first of its kind - in the mid-1980s - to offer institutional synergies between practice and social justice, with a focus on gender rights. Flavia Agnes, another senior lawyer, founded (along with Madushree Dutta, an activist) a legal resource center for

${ }^{19}$ We make this distinction to highlight the trajectory of other women who do this ad-hoc lecturing from positions of much less agency / power and therefore have to succumb to exhausting teaching loads rather than expansive political/social agendas. 
women called Majlis. In addition to being practitioner-activists, Agnes and Jaising are also respected scholars whose writing have been published in popular and academic outlets alike (Agnes 1995; Jaising 2000). Other exemplars of this practitioner-scholar model include feminist lawyers Asmita Basu and Vrinda Grover.

Beyond the examples within law schools and women in quasi-law sites, alternate sites and actors have produced important work about which law school environments have largely been ambivalent. Non-lawyers have been prominent contributors to the scholarship about women and the law (eg, Sarkar 1991; Nair 1996; Mazumdar 1999; Menon 2001, Patel 2002, Singha 2003, Menon 2004, Roy 2005, Khullar 2005, Anagol 2005, Geetha 2006; Swaminathan 2009; Geetha 2015) as well as to the co-creation of law-bridging academic networks and collaborative research groups we mention above (eg, LASSNET was started by Pratiksha Baxi). As we allude to earlier in this chapter, non-law professors in law schools have to constantly contend with the hurdle of boundary marking (eg, Mukhija 2016) and interdisciplinary scholarship in general both struggles and benefits from being a boundary straddle. In the law school context, this wealth of work often goes underappreciated because the authors, despite having a strong focus on law and legal systems are not very visible beyond their women's studies audience. One could make the case that this is largely because law schools in India teach predominantly using case law. But even where this is so, subjects like legal theory and jurisprudence (required courses as per the University Grants Commission for law schools) remain taught with legal debates and ancillary writing, but without very much concentration on this rich literature on feminist method and theory.

\section{Conclusion}

Law has been central to the feminist project and feminist lawyers have been central to reshaping legal discourse and culture (Baxi 2016:86). And yet, one would be hard pressed to argue that it is feminist tools from their legal education that has shaped their contributions. Law schools in India remain very male spaces - and the gendering of incoming student cohorts has not changed the gendering of the people who train them. With few exceptions, to the extent women have made headway in the majority of these schools, it has been a function of their own independent resistance and ability to repurpose their environments to their advantage. Yet, this is not to say India has a dearth of important legal writing by female scholars or a lack of substantial feminist critique. And as we argue, focusing beyond law schools as sites of creation give us a sense of the wide range of contributions made in these areas by women. It also serves as a reminder that the creation of this resistance has happened not because of - but, rather, despite - the presence of these formal institutions of legal education.

Finally, it is not just the feminist voice that has become marginal in this law school context. As in other professional schools (eg Maharatna 2014; Joshi and Malghan 2017), the advent of liberalism has made law schools mostly apolitical. And as other scholars have expressed, there remains a vast divergence between the original vision of the NLUs as schools motivated by social justice ideals and pro-industry choices endorsed by its graduates through class selection and recruitment. For the most part, and as in other countries (Thornton 2001), predatory capitalism, manifest in institution of the corporate law firm, has its claws firmly planted in the law school - dictating student choices and even university curricula 
(Gudavarthy 2004; Gingerich and Robinson 2014). Law schools have transmorphed into 'institutes' for imparting technical proficiency and creating professionals to service the interests of global capitalism. Given that feminist research is a political project (Kannabiran and Swaminathan 2016), the questions remains whether law schools can continue to stay apolitical and ignore the critical feminist debates that concern our contemporary times. 


\section{Bibliography:}

Anagol, P (2005) The Emergence of Feminism in India 1850-1920 (Aldershot, Ashgate).

Agnes, F (1995) State, Gender and the Rhetoric Of Law Reform (Mumbai, RCWS).

Ballakrishnen, S (2019) 'Present and Future: A Revised Sociological Portrait of The Indian Legal Profession' in H Sommerlad, O Hammerslev, R Abel and U Shultz (eds), Lanyers in Society: Thirty Years On (London, Hart) In Press.

-- (2018) 'Nevertheless They Persisted: Gendered Frameworks and Socialization Advantages in Indian Professional Service Firms' Canadian Review of Sociology (forthcoming).

-- (2017) 'Women in India's "Global Firms: Gender Frames and Advantages of New Organisations' in D Wilkins, V Khanna and D Trubek (eds), The Indian Legal Profession in The Age of Globalisation (Cambridge, Cambridge University Press).

Basheer, S and Sharma, G (2014), 'IDIA Diversity Survey (2013-2014): Analysis And Policy Recommendations,' www.idialaw.com/wp-content/uploads/2015/02/Top-5-Analysis.pdf.

Baxi, P (2008) 'Feminist Contributions to the Sociology of Law: A Review' 43(43) Economic and Political Weekly 79-85.

-- (2008) 'Impractical Topics, Practical Fields: Notes on Researching Sexual Violence in India' 51(18) Economic and Political Weekly 80-88.

-- (2016) 'Carceral Feminism' as Judicial Bias: The Discontents Around State v. Mabmood Farooqui 3 Interdisciplinary Law.

Baxi, U (1976) 'Notes Towards a Socially Relevant Legal Education' 5 Journal Of The Bar Council Of India 23.

-- 2007 'Enculturing Law? Some Unphilosophic Remark', in M John and S Kakarala (eds.) Enculturing Law: New Agendas for Legal Pedagogy 2 (New Delhi, Tulika Books).

Bhatt, E (1989) 'Toward Empowerment' 17(7) World Development 1059-1065.

Centre for the Study of Culture and Society (CSCS) (2005) 'Enculturing Law: New Agendas for Legal Pedagogy' www.cscs.res.in/events_folder/abevents.2008-0319.7207306363/abevent.2008-03-25.5594652952.

Dhanda, A (2009) 'The Power of One: the Law Teacher in the Academy' in A Dhanda and A Parashar (eds), Decolonisation of Legal Knowledge 261 (New Delhi, Routledge India).

Dhanda, A and Parashar, A (1999) Engendering Law: Essays in Honour of Lotika Sarkar (Allahabad, Eastern Book Company). 
Gersen, J S (2014) 'The Trouble With Teaching Rape Law' New Yorker (15 December) www.newyorker.com/news/news-desk/trouble-teaching-rape-law.

Gingerich, J and Robinson, N (2014) 'Responding to the Market: The Impact of the Rise of Corporate Law Firms on Elite Legal Education in India' 11 HLS Program on the Legal Profession Series www.ssrn.com/abstract $=2398506$ or www.dx.doi.org/10.2139/ssrn.2398506.

Geetha, V (2006) Theorising Feminism: Gender (Stree, Calcutta).

-- (2015) 'Some Thoughts on Extreme Violence and the Imagination' 50(44) Economic \& Political Weekly 85-91.

Gudavarthy, A (2004) 'Tailored for the corporates?' The Hindu (2 November) www.thehindu.com/2004/11/02/stories/2004110203131000.htm.

Gutiérrez y Muhs, G., Niemann, YF., Gonzalez, CG. \& Harris, AP (2012) Presumed Incompetent: The Intersections of Race and Class for Women in Academia (Boulder, Utah State University Press).

Haksar, N (1999) 'Human Rights Lawyering: A Feminist Perspective' in A Dhanda and A Parashar (eds) Engendering Law: Essays in Honour of Lotika Sarkar 71-88 (Allahabad, Eastern Book Company).

Jaising, I (2000) 'Gender Justice and the Supreme Court' in Kirpal et al (eds), Supreme But Not Infallible: Essays in Honor of the Supreme Court of India (New Delhi, Oxford University Press).

Joshi, S and Malghan, D (2017) 'Faculty Diversity at the IIMs: A Preliminary Snapshot,' 52(13) Economic \& Political Weekly 12-14.

Jain, C et al (2015) 'The Elusive Island of Excellence' www.papers.ssrn.com/sol3/papers.cfm?abstract_id=2788311.

Justice Verma et al (2013) 'Report of the Committee on Amendments to Criminal Laws' (January 23) www.prsindia.org/uploads/media/Justice $\% 20$ verma $\% 20$ committee/js $\% 20 \mathrm{verma} \% 20$ commi tte\%20report.pdf

Kannabiran, K (2005) 'Towards an Inclusive Praxis in Law: Questions on Pedagogy, Diversity and Rights' National Conference of Women's' Studies.

-- (2006) 'The Rule of Law, Rights Discourse and Separate Spheres Kalpana Kannabiran' unpublished, on file with authors.

-- (2012) Tools of Justice: Non-discrimination and the Indian Constitution (New Delhi, Routledge).

-- (2014) 'Preface' in K Kannabiran (ed), Women and the Law: Critical Feminist Perspectives (New Delhi, SAGE). 
Kannabiran, K and Swaminathan, P (2016) 'Feminist Research is a Political Project' 51(18) Economic \& Political Weekly 37-38.

Khullar, M (2005) Writing the Women's Movement: A Reader (New Delhi, Zubaan).

Krishnan, Jayanth K (October, 2004) 'Professor Kingsfield Goes To Delhi: American Academics, The Ford Foundation, And The Development Of Legal Education In India' 46 Am. J. of Legal Hist. 447.

Maharatna, A (2014) 'A Civilisational Casualty?: Invasion of Educational Universe by Neoliberal Economic Thinking’ 49(37) Economic and Political Weekly 80-87.

Mazumdar, V (1985) Emergence of the Women's Question in India and the Role of Women's Studies (New Delhi, Centre for Women's Development Studies).

--(1999) 'Political Ideology of the Women's Movement's Engagement with Law' in A Dhanda and A Parashar (eds) Engendering Law: Essays in Honour of Lotika Sarkar (Allahabad, Eastern Book Company).

Menon, N (2001) 'Embodying the Self: Feminism, Sexual Violence and the Law' 11 Subaltern Studies 66-105.

-- (2004) Recovering Subversion: Feminist Politics Beyond the Law (Chicago, University of Illinois Press).

Menon, NRM (2010) 'To Go From Mediocrity to Excellence' The Hindu (18 June) www.thehindu.com/opinion/lead/To-go-from-mediocrity-toexcellence/article16256292.ece.

Michelson, E (2013) 'Women in the Legal Profession, 1970-2010: A Study of the Global Supply of Lawyers' 20 Ind. J. Global Legal Stud. 1071.

Mishra, S (2016) 'I was sexually harassed in the corridors of the Supreme Court' The Week (13 November) www.theweek.in/theweek/cover/interview-indira-jaising-senior-lawyer.html.

Mossman, MJ (2006) The First Women Lawyers: A Comparative Study of Gender, Law and the Legal Professions (Bloomsbury).

Mukhija, N (2016) 'FemTalk \#1: Prof. V. Elisabeth on Feminism, NLS, and Armchair Activism' www.thefeministmarshmallow.wordpress.com/2016/02/26/femtalk1-prof-v-selisabeth-on-feminism-nls-and-armchair-activism/.

Nair, A (2013) 'No Male Student so far at ILS Women Studies Centre' Indian Express (8 March) www.archive.indianexpress.com/news/no-male-student-so-far-at-ils-women-sstudies-centre/1084866/

Nair, J (1996) Women and Law in Colonial India (New Delhi, Kali for Women).

Nalsar (2017) 'Nalsar Youtube Channel’ www.youtube.com/user/NalsarITDept/playlists 
NLSIU (2014) 'List Of Guest Lectures Held at NLSIU at a Glance from July 2013 to June 2014' www.nls.ac.in/resources/guestlecturesjul2013june2014.pdf.

--(2015) 'Guest Lectures at NLSIU from July to December 2015' www.nls.ac.in/resources/guestlecturesjulytodec2015.pdf.

Patel, V (2002) Women's challenges of the new millennium (Delhi, Gyan Books).

--(2013) 'In Memorium: Lotika Sarkar 1923-2013' www.feministsindia.com/in-memoriamlotika-sarkar-1927-2013/

Ramanathan, U (2013) 'The Mind and Heart of Lotika Sarakar, Legal Radical, Friend, Feminist' www.kafila.online/2013/03/08/the-mind-and-heart-of-lotika-sarkar-legal-radicalfriend-feminist-usha-ramanathan/.

Ridgeway, C (2011) Framed by Gender: How Gender Inequality Persists in the Modern World (Oxford, Oxford University Press).

Rajkotia, M (2017) Intimacy Undone: Marriage, Divorce and Family Law in India (Delhi, Speaking Tiger).

Report of the Committee on the Status of Women (1975) 'Towards Equality' www.feministlawarchives.pldindia.org/category/towards-equality/towards-equality-towardsequality/.

Roy, A (2005) Gendered citizenship: Historical and Conceptual Explorations (New Delhi, Orient Blackswan).

Sarkar, L (1995) 'Women's Movement and the Legal Process’ 24 Occasional Paper Series, Centre for Women's Development Studies.

Sarkar, T (1991) 'Reflections on Birati Rape Cases: Gender Ideology in Bengal' 26(5) Economic and Political Weekly 215-218.

Sharma, K (1998) 'Power v. Representation: Feminist Dilemmas, Ambivalent State and the Debate on Reservation for Women in India' 28 Occasional Paper Series, Centre for Women's Development Studies.

Singha, R (2003) 'Colonial law and Infrastructural Power: Reconstructing Community, Locating the Female Subject' 19(1) Studies in History 87-126.

Sircar, O (2016) 'The Fraught Terrain of Law And Feminism: 20 Years Of Subversive Sites' 12(1) Socio-Legal Review 133-152.

Sood, M (2013) 'Opinion: In One of India's 'Most Sexist Professions', Harassment By Powerful Men is Rife' Legally India (18 November) www.legallyindia.com/home/indiasmost-sexist-profession-harassment-20131118-4119. 
Sorabji, R (2010) Opening Doors: The Untold Story of Cornelia Sorabji, Reformer, Lawyer and Champion of Women's Rights in India (New Delhi: Penguin Books).

Staff Reporter (2012) 'Committee absolves ex-Nalsar VC of sexual harassment charges' Legally India (April 12) www.legallyindia.com/lawschools/committee-absolves-ex-nalsar-vcveer-singh-of-dhanda-sexual-harassment-20120417-2748

Stewart, A (1995) 'Debating Gender Justice in India' 4(2) Social and Legal Studies 253-274.

Swaminathan, P (2009) 'Outside the Realm of Protective Labour Legislation: Saga of Unpaid Labour in India' 44(44) Economic and Political Weekly 80-87.

Thornton, Margaret (2001) 'The Demise of Diversity in Legal Education: Globalisation and the New Knowledge Economy' 8(1) International Journal of the Legal Profession 37-56.

V S Elisabeth (2011) 'Teaching Law from a Feminist Perspective' Conference Presentation, International Association of Law Schools Conference on "Teaching Legal Education and Strategic Panning”, Buenos Aires, April 13-15 available at www.ialsnet.org/wordpress/wpcontent/uploads/2015/08/Elisabeth.pdf. (last accessed December 2017, archived text on file with authors). 


\begin{tabular}{|l|c|c|c|c|c|c|c|c|}
\hline $\begin{array}{l}\text { Law } \\
\text { School }\end{array}$ & \multicolumn{7}{|l|}{ Number of Women Faculty in the NLUs } \\
\hline $\begin{array}{l}\text { Professor } \\
\text { Status }\end{array}$ & Full & $\begin{array}{l}\text { Chair/ } \\
\text { Honorary }\end{array}$ & Associate & Assistant & Adjunct & Visiting & $\begin{array}{l}\text { Ad hoc } \\
\text { Assistant }\end{array}$ & $\begin{array}{l}\text { Research } \\
\text { Associate }\end{array}$ \\
\hline NLSIU & 1 of 7 & 0 of 5 & 1 of 3 & & 0 of 4 & 0 of 8 & 9 of 26 & \\
\hline $\begin{array}{l}\text { NALSA } \\
\text { R }\end{array}$ & 3 of 8 & & 1 of 2 & 4 of 24 & & & & \\
\hline NUJS & 0 of 4 & & 1 of 3 & 4 of 20 & & & & \\
\hline $\begin{array}{l}\text { NLIU, } \\
\text { Bhopal }\end{array}$ & 0 of 6 & & 4 of 6 & 3 of 11 & & & \\
\hline $\begin{array}{l}\text { NLU, } \\
\text { Jodhpur }\end{array}$ & 1 of 3 & & 2 of 4 & 12 of 25 & & 1 of 9 & & \\
\hline $\begin{array}{l}\text { NLU, } \\
\text { Delhi }\end{array}$ & 2 of 6 & 1 of 9 & 6 of 11 & 8 of 19 & & 0 of 2 & & 4 of 7 \\
\hline
\end{tabular}

Table 1. This data has been sourced from the college websites and is reflective of the faculty listings as at $5^{\text {th }}$ March, 2017.

\begin{tabular}{|l|c|c|c|c|}
\hline Law School & \multicolumn{3}{|c|}{ Number of Women Faculty in Law Departments in Public Universities. } \\
\hline $\begin{array}{l}\text { Professor Status } \\
\text { Campus } \\
\begin{array}{l}\text { Centre, } \\
\text { University }\end{array}\end{array}$ & Full of 4 & Associate & Assistant & Ad hoc / Assistant \\
\hline $\begin{array}{l}\text { Law Centre 1, } \\
\text { Delbi University }\end{array}$ & 1 of 1 & of 5 1 of 26 \\
\hline $\begin{array}{l}\text { Government Law } \\
\text { College, Bombay } \\
\text { University }\end{array}$ & - & 1 of 1 & 6 of 13 & 10 of 26 \\
\hline
\end{tabular}

Table 2. This data has been sourced from the college websites and is reflective of the faculty listings as at $5^{\text {th }}$ March, 2017. Note that the Government Law College, Bombay University, established in 1885, is the oldest law college in Asia.

\begin{tabular}{|l|c|c|c|c|}
\hline Law School & \multicolumn{3}{|l|}{ Number of Women Faculty in Private Law Schools } \\
\hline Professor Status & Full & Associate & Assistant & Research Associates \\
\hline $\begin{array}{l}\text { Jindal Global } \\
\text { Law Scbool }\end{array}$ & 1 of 10 & 10 of 27 & 26 of 52 & 17 of 25 \\
\hline
\end{tabular}

Table 3. This data has been sourced from the college website and is reflective of the faculty listings as at $5^{\text {th }}$ March, 2017 